doi $\underline{\text { http://dx.doi.org/10.18542/rmi.v15i24.10042 }}$

Margens: Revista Interdisciplinar | e-ISSN:1982-5374 | V. 15 | N. 24 | Jun, 2021, pp. 211-235.

\title{
HISTÓRIA E CINEMA: UMA LEITURA ICONOGRÁFICA DA MODERNIDADE
}

\section{HISTORY AND MOVIE THEATER: AN ICONOGRAPHIC READING OF MODERNITY}

\author{
Edinei Pereira Pereira da SILVA (PUC-SP) ${ }^{1}$
}

Resumo: O presente artigo tem como escopo tratar o cinema como consequência das transformações proporcionadas pelo desencadeamento da Modernidade. Os elementos constituintes e capturados pelas lentes cinematográficas, além dos grandes e visibilizados fatos já apontados pelos estudos historiográficos, passam pelas relações do cotidiano, aqueles que muitas vezes são geridos pelas forças do controle do tempo. Este, problematizado aqui como substância de um capitalismo que se coloca como normatização daquela organicidade. Algumas obras fílmicas foram pensadas para fundamentar o estudo. Como: Metropolis (de Fritz Lang), e Tempos Modernos (de Charles Chaplin). Ambas trazem uma série de questões pertinentes para uma análise à luz daquela conjuntura. Procurei esquadrinhar as cenas que remetiam de forma direta ao Tempo como substância elementar daquela realidade, e suas conjunções ao que implica na alteração e consequência do homem moderno a partir da leitura iconográfica.

Palavras-chave: Cinema. Modernidade. Tempo.

\begin{abstract}
This article has like a scope deal with movie theater as consequence of changes by the development of modernity. The elements captured by cinematic lenses, beyond big facts shown by the historiographies studying, passing by daily relation, those which many times are managed by the time. This one, problematized here like capitalism substance placed as standardization about organization. Some films were done to fund the study. For example: Metropolis (Lang, Fritz), and Tempos Modernos (Chaplin, Charles). Both bring a lot of questions for an analysis of that conjuncture. Searched scan scenes that bring the direct form to Time as an elementary substance about that reality, and your conjunctions which implies in alternation and consequences of modernity man from iconographic reading.
\end{abstract}

Keywords: Movie theater. Modernity. Time.

\footnotetext{
${ }^{1}$ Mestre em História Social pela PUC-SP (2019). Participa do Núcleo de Estudos em História Social da Cidade (NEHSC), coordenado pela professora Dra. Yvone Dias Avelino. Atualmente é professor na Rede Estadual de Ensino do Estado de São Paulo, com ênfase nas matérias de Sociologia e História. E-mail: edineipereira29@yahoo.com.br
} 


\section{INTRODUÇÃO}

As convergências dos vários acontecimentos que se convencionou chamar de Modernidade, sobretudo em decorrência da dinamização da Revolução Industrial do século XVIII, resultaram na criação e aperfeiçoamento de técnicas concebidas pela burguesia como instrumento condutor de seus planos práticos. Para além dessas correlações de forças, meu intento ao longo do artigo é de trazer o cinema como uma linguagem resultante desse processo, que pudesse instrumentalizar nosso olhar para os fatos, assim como compreender seus impactos no cotidiano.

Trazer o cinema para o presente trabalho é atrelá-lo a uma leitura iconográfica das relações sociais, de modo que os grandes feitos são percebidos pelas costuras de ações dos comportamentos dos sujeitos comuns, ou seja, a elaboração de um entendimento macro de uma realidade, que tem como ponto de partido o micro. Ou aquilo que está intrínseco nas particularidades das ações do cotidiano. Enquanto ao estudo das imagens, Peter Burke nos aponta que "devemos prestar atenção aos detalhes [...] para identificar significados culturais" (BURKE, 2017, p. 62).

Esses detalhes podem nos fornecer pistas, as quais nos guiam por um caminho estruturado na realidade cotidiana. Quero dizer com isso que o filme pode ser entendido como um documento histórico que nos permite ter a dimensão de seus elementos estéticos e técnicos, que são imprescindíveis. Além de pensar no impacto das evoluções no âmbito de um labor que se reinventa, e olhando para o sujeito histórico que esteve operando incessantemente a máquina, sendo supervisionado constantemente por outrem.

O fator Tempo foi inserido aqui para denotar as maneiras como essas teias de acontecimentos se entrelaçam. O tempo, portanto, se configura como uma substância desse Moderno. Não só pelas rotas criadas para conexão de lugares até então distantes, mas pelo que representou nas profundas normatizações intensamente inseridas nos modos e hábitos das pessoas. Essas leituras, por certo, não esgotam aquilo que realço ao longo desse trabalho, e sim suscitam outras reflexões acerca de um período distante, que de maneira performática suas consequências reverberam ainda hoje.

Por isso, é que em virtude do mencionado, trato ao longo das linhas subsequentes sobre História e Cinema a partir de uma leitura iconográfica das imagens capturadas pela arte cinematográfica, além de fazer uma breve análise do quadro do pintor espanhol Pablo Picasso. Todavia, penso que isso se deu para que o tema da "iconografia" fosse tratado à guisa das pretensões introdutórias, o que evidentemente não esgota o que a mencionada arte tem a nos dizer sobre os tristes acontecimentos do povoado basco. Nessa perspectiva, como já dito aqui, o filme é posto como um documento, que lido nas suas entrelinhas nos fornece informações substanciosas acerca de uma 
conjuntura toda pautadas nos grandes e pequenos eventos. Aqueles criados e tecidos cotidianamente pelos sujeitos históricos, homens e mulheres comuns.

\section{LEITURAS PRELIMINARES DAS PRÁTICAS SOCIAIS DA URBANIDADE SOB O PRISMA DA ARTE CINEMATOGRÁFICA.}

Antes de adentrar especificamente no terreno correspondente aos elementos concebidos pela historiografia brasileira, de maneira a tratar os traços que correlacionam sua história cultural e os elementos que constituem a vida dos sujeitos, sobretudo dos homens que vivem às margens dessa sociedade, trago para contribuir com esse trabalho o pensamento de alguns teóricos que nos ajudam significativamente com algumas questões, assim como problematizo conceitos pertinentes ao desenvolvimento e solidificação do que veio a ser a Modernidade. Além de pensar o cinema como uma das consequências desse processo de consolidação alicerçado nas contradições do cotidiano.

Ao tratar essas questões, esclareço como as invenções são permeadas por relações sociais, e suas práticas implicam diretamente na organicidade da urbanidade. Isso, portanto, me leva a colocar o cinema como resultado dessas mudanças. Ou seja, como consequência de fatores que dinamizaram, com o advento de tantas outras invenções, e estabeleceram como critério de uma lógica ancorada nos respingos dos inventos, um mundo a ser compreendido, também, pela linguagem cinematográfica. Contudo, problematizar essas elucubrações nos faz trazer para a superfície dos fatos outros pontos de igual importância, e que servem de base para nosso estudo.

Pretendo, entre outras coisas, pensar o mundo envolto nas contradições daquela sociedade. E mediante as alterações das consequentes "induções"2 da industrialização, tecer as teias que costuram esses eventos carregados de tensões. Todavia, partindo dessa premissa, a História é concebida aqui como aquela vista de baixo, ou seja, das minúcias que nem sempre são realçadas pela historiografia oficial. É a História dos acontecimentos relegados para um segundo plano, que propõe evidenciar as bordas, aquilo que norteia a vida dos marginalizados.

Para entender o Marginal como sujeito histórico e, parte integrante dessa correlação de forças, é importante apontar que esse não é um excluído, pois encontra-se ativo nas bordas, à margem. Mesmo que impactado com as transformações avassaladoras que normatizou uma lógica capitalista

\footnotetext{
${ }^{2}$ O sentido da palavra "Indução” significa que: as consequências do processo da industrialização, ou seja, na correlação de forças que emergem diante do processo dessa industrialização, as cidades passam a ganhar uma nova dinâmica, a urbanização passa a ser constituída pelos frutos dessa "indução"; como a energia elétrica, as vias férreas, além de uma relação social que é alterada com essa dinamização. Para melhor compreender esse conceito. Ver: LEFEBVRE (2016).
} 
por meio da modernização. Esse, ao longo da história, nos permite observar as inconsistências desse sistema que se consolidava. Jean Claude Schmitt assim descreve esse momento:

Entretanto, pesava sobretudo o peso das massas desarraigadas pela Revolução Industrial, frescamente urbanizadas e facilmente desqualificada. Aliás, colocava-se o problema de uma continuidade entre arraia-miúda, o popolo minuto, das cidades do Antigo Regime, e a classe operária do mundo capitalista. (SCHMITT, 2011, p. 262).

Com isso, chamo atenção para os detalhes das transformações que normalmente são sentidas e, consequentemente convertidas como foco de reflexão para os sujeitos impactados pelos pontos que nortearam, e atravessaram essa realidade. Mas, antes, fazem-se necessárias algumas questões que são imprescindíveis para maior compreensão dos fatos aqui apontados, com os quais fundamento o artigo.

Walter Benjamin (1989), entre outras questões, debruçou-se sobre a temática da Modernidade. Em seus escritos essa questão é bastante recorrente, pois sua preocupação com a técnica empregada como forma de apropriação das artes, e o uso dessas, por sua vez, é de caráter prognóstico, ou seja, apontam para a necessidade de compreender as consequências da cultura, e como esta, de certo modo, moldaria as relações sociais do século XX, e dos períodos subsequentes.

Por meio de um olhar mais preciso nas entrelinhas do que propôs este autor, faz-se notar que àquela altura o mundo absorvia parte do que anos atrás fora despendido como consequência das alterações das invenções desencadeadas pela Revolução Industrial. Como, por exemplo: um novo modo de produção, a emergência das máquinas a vapor e de tear. E, mais adiante, do telégrafo, do carro, entre outros.

Junto a isso, ainda como temas adjacentes à constante profusão de acontecimentos decorrentes do período propagador dessa urbanização, e dos meios que intensificaram a dinamização de suas artérias, é importante notar que as tensões que o próprio Benjamin vivenciou estavam diretamente ligadas a essas vertentes. Entretanto, nos interessam particularmente as mudanças iniciadas já no século XVIII, como aqui descritas, mas que se avolumam como finalidade imanente do século XX. Quero dizer com isso que suas mudanças não se limitam aos pontos que estruturam na vida material, no sentido de pensar as construções e os sentidos dados à lógica capitalista, a saber: estradas, praças e monumentos. Mesmo sendo possível pensarmos essas práticas como o resultado de uma relação do cotidiano.

Mesmo que esses carreguem no seu bojo o sentido das práticas sociais e realizações que muitos dizem acerca de um dado período, é importante constatar alguns aspectos dessa arte a partir 
do prisma de uma relação precedida de choques, lutas e contradições. Da mesma forma que acontecem sistematicamente nas experiências cotidianas dos sujeitos sociais dessas transformações.

Essas práticas, portanto, podem ser constatadas quando Walter Benjamin nos apresenta o seu Flâneur ${ }^{3}$, que é útil nesse primeiro momento, sobretudo para evidenciar a cidade distópica, e que, nessa mesma linha, também foi utilizada por alguns cineastas, como representação histórica.

Como exemplo, cito Ozualdo Candeias, que no filme A Margem, de (1967) ${ }^{43}$, por meio do andarilhar de seus personagens, embrenhou-se nas multidões como um típico testemunho das constantes alterações da cidade, que absorveu as marcas dessa atmosfera modernizadora.

Isso é posto para nós sob a ótica do andarilho, aquele que poeticamente escreve os lugares, tido como o homem das multidões, conceito usado por Benjamin para tipificar aquele que flana, caminha pelas ruas da cidade anunciando o luxo das galerias, e "as fumaças das altas chaminés da fábrica..." (BENJAMIN, 1989, p 36). A distopia consiste no que testemunham tanto o Flâneur de Benjamin, assim como os sujeitos deambulantes de Ozualdo Candeias. Pois evidenciam os elementos contraditórios de uma sociedade que se coloca diante dessas constantes mudanças, num mundo paradoxal, desfigurado e fragmentado.

É importante entender que o escrito desse pensador se coloca como de grande valia, principalmente quando procuramos problematizar as consequências e, sobretudo, os impactos que causaram nas gerações posteriores. Sua linguagem metafórica não esconde os fatos tais quais ele colocou nas entrelinhas do processo histórico. Pois as "galerias" desenhavam o requinte que a urbanização representava àquela altura, as "chaminés das fábricas " nos direcionam para um universo pautado na inserção de uma sociedade em vias de crescimento, mesmo que de forma desigual.

Todas essas questões, as criadas pela Modernidade, são suscitadas de maneira que constatamos choques, no sentido de colisão, ou seja, não foi algo que levou benefício para todos os lados. Tornou dissonante uma realidade em que as novas invenções se faziam chegar. Os paradoxos logo se colocaram como pauta para a compreensão de uma história que pendia para os "grandes" acontecimentos, em detrimento dos fatos "menores", que foram, muitas vezes, tangenciados pelo transcurso do processo histórico. Ao tratá-los na sua análise, traz-os para a superfície dos acontecimentos.

\footnotetext{
${ }^{3}$ Para Walter Benjamin, o Flâneur é aquele que caminha, flana, andarilha pela cidade. É o homem das multidões que constata as transformações do espaço, assim como a relação em que as pessoas estão submersas. Ver: BENJAMIN (1989). ${ }^{43} \mathrm{O}$ filme a Margem, de Ozualdo Candeias, foi tema da minha dissertação de Mestrado, cujo título é Às margens da Margem: o cinema como prática de resistência, e os sujeitos deambulantes no filme de Ozualdo Candeias (1967-1970). Defendida em 2019 no Programa de Pós-Graduação em História Social na Pontifícia Universidade Católica de São Paulo (PUC-SP).
} 
Para o estudo de qualquer temática histórica, além de se levar em conta sua temporalidade, espacialidade, e o período, lugar que se desenvolveu tal movimento, o objeto e as questões nele intrínsecos podem ser compreendidos a partir das práticas sociais que levaram a algumas descobertas, a exemplo do Cinema, escopo deste artigo.

Em vista disso, vislumbro que: pensar o cinema a partir das consequentes transformações impostas pela industrialização, e, por conseguinte, da urbanização como fio condutor dessa dinamização, é ter como essência dessas correlações o fato preponderante das práticas sociais. Para além dessas costuras de acontecimentos, o que permeia as linhas subsequentes deste trabalho, será comprovar o sentido que implica o tempo como substância dessa modernidade, se pensarmos em algumas filmografias e os sentidos de suas mensagens, e como foram representadas. Essas questões significativas, portanto, nos dão base para elucidar outros pontos atrelados à História do cinema $^{54} \mathrm{e}$ sua relação com a sociedade tida como Moderna.

A história do cinema está ligada diretamente ao processo que culminou na urbanização, ou na aceleração decorrente de uma série de transformações oriundas de sua dinamização, e, por conseguinte, aos pontos que nortearam seu desenvolvimento. Podemos dizer que é o resultado das mudanças ocorridas durante o século XVIII, período em que a industrialização aparece como fator determinante para a ruptura, e/ou mudanças daquilo que ainda persistia nas cidades, como as relações comerciais. Contudo, analiso a conjuntura, ao passo que tomo como vértice as particularidades de cada ação, que considero como de suma importância para a compreensão dos fatos aqui analisados. E busco por meio desses acontecimentos, problematizar algumas questões que considero imprescindíveis para o surgimento do cinema como elemento constitutivo dessa narrativa, é parte intrínseca dessas vicissitudes.

Os pontos que nortearam a chegada desta arte aos vários espaços, e que nos possibilita tratálos a partir da constituição de uma arte cinematográfica em vias de consolidação e disputas por territórios, mediante a apropriação dos vários sujeitos como parte integrante desse universo, não é estanque. Pois possui suas variações ao longo da História. Sua solidificação é posta para os estudos historiográficos como sendo, em sua essência, carregadas de tensões. Isso justifica seu caráter dinamizador.

\footnotetext{
${ }^{54}$ Para compreender a história do cinema, essa obra se faz imprescindível no que toca aos primeiros eventos desta arte. Durante a leitura do livro a autora nos fornece, de maneira clara, conceitos empregados por pessoas especializadas no tema, mas, que, devido à sua escrita, podem ser compreendidos por iniciantes no tema. Ver: CESARINO (2005).
} 
A industrialização mudou a lógica das cidades assim como as atividades ali existentes, e, por conseguinte, das relações sociais até então vigentes, acelerando sua dinâmica e criando uma série de invenções: como a eletricidade.

Dito isto, as alterações deram ao fator tempo e às espacialidades um novo sentido. Essa intersecção, além de reduzir/derrubar o distanciamento entre alguns lugares, fez emergir como parte integrante desta narrativa, entre outras coisas: o cinema, as ferrovias, etc. Em decorrência disso, das questões elementares nessa costura de acontecimentos, dimensionamos os diferentes jeitos de se ler iconograficamente as práticas que se alicerçaram, por meio das ações dos sujeitos históricos daquela conjuntura. Isso, portanto, caracteriza tanto uma nova atmosfera, quanto assinala novas anomalias no campo social, como consequência direta dessa urbanização. Mas que é posta aqui como fator determinante para a criação de uma linguagem que se colocava como revolucionária naquele momento, a propósito de sua "magia" e resistência.

Isto posto, constatei que os espaços ocupados foram subvertidos pelos sujeitos em meio à modernidade. Mais adiante pretendo discorrer de forma mais detalhada acerca desse cinema que nasce e se desenvolve como fruto desse mundo em ebulição. Mas, antes, cabem algumas ponderações acerca dos fatos que o antecederam.

O Diálogo narrativo composto por esses fatores, pressupõem a retomada de alguns pontos centrais e essenciais no transcurso desta consolidação artística, assim como nos faz entender a organicidade dessas artérias que se entrecruzam. As cidades aqui são postas como artérias pulsantes de um cotidiano que se configura em meio às articulações desses novos eventos. Portanto, as cidades se constituíram como lugar por excelência daquele modus operandi. Sua composição é notabilizada por uma série de acontecimentos que remontam a um período antes mesmo da eclosão das cidades comerciais da idade média, mas que só passam a ganhar novos contornos, ou seja, novas características em suas vias, a exemplo das estradas e todo aparato pensado para/pela burguesia comercial, com o advento do século XVIII. Junto a isso, os sujeitos, principalmente os marginalizados, aqui são pensados como composição indissociável daquele constructo social.

O tempo e toda a gama de invenções que caracterizam essa modernidade passam por uma multiplicidade de mudanças no plano social. Seu caráter histórico vai triunfar e se fazer mais claro e consistente a partir do século XIX, sobretudo com a revolução científico-tecnológica, o que entendo como a continuação, e/ou aperfeiçoamento da Revolução industrial que ocorreu a partir do século XVIII na Inglaterra, e começou a alterar aquele mundo, como preparando as bases para a posterior solidificação dos espaços praticados pelos sujeitos históricos (HOBSBAWM, 2011). 
Isso quer dizer que, mediante o uso da arte, consequência dessa trama, os sujeitos puderam subverter a ordem estabelecida, dando assim um novo sentido para os aspectos sociais até então em voga. O tempo, que outrora exercia uma finalidade dispare, com a Modernidade se torna parte dos planos de controle impostos pelo avanço capitalista. E o cinema, posto aqui como um documento, nos permite fazer essa leitura.

\section{A ICONOGRAFIA COMO APORTE ANALÍTICO}

É factível uma leitura dos documentos históricos como elementos que constituem os múltiplos caminhos para uma determinada análise. A constatação desses elementos pode se dar por meio do enxergar para além do que está posto, do perceptível. Ou seja, é nas entrelinhas que podemos testemunhar o que muitas vezes a superfície dos acontecimentos não nos permite ver. Para tanto, Peter Burke (2017) nos fornece uma ferramenta de análise para que possamos compreender essas constatações: que é a iconografia. Diante disso, para o autor, faz-se necessário:

Levar em conta mudanças no tipo de imagem disponível em lugares e épocas específicos, e especialmente duas revoluções na produção de imagens: o surgimento da imagem impressa (gravura em madeira, entalhe, gravura em àgua-forte etc.) durante o século XV e XVI, e o surgimento da imagem fotográfica (incluindo o filme e a televisão) (BURKE, 2017, p. 28-29).

Podemos inferir com isso que: o autor faz um recorte histórico da evolução da imagem, e dimensiona, com a providencial observação do que pode ser passível de uma análise iconográfica. $\mathrm{O}$ que nos faz entender que desde um jornal impresso, pinturas, passando pelas imagens em movimento (como é o caso do cinema, que surge no final do século XIX), podem ser objetos de estudos. Outro ponto pertinente do trecho acima é o fato de termos o recorte de espaço e tempo, o que pressupõe dizer que ao tratar de uma pintura, por exemplo, temos que levar em consideração uma série de fatores que direta e/ou indiretamente fazem parte de sua constituição histórica, assim como pode possibilitar para o investigador pistas para os enigmas a serem decifrados.

Os indícios para tais constatações partem substancialmente das relações sociais. As condutas e comportamentos dos sujeitos de uma determinada época, que são tidas como elemento condutor, e que alicerça aquele caminho a ser percorrido de maneira a evidenciar os reais sentidos de uma dada sociedade. Isso é o que compõem a esteira de acontecimentos que nos guia para o que objetivamos: fazer um estudo iconográfico de algumas imagens no âmbito da modernidade. 
Para Carlos Ginzburg (2014), em "Medo reverência e terror: quatro ensaios de iconografia política", ao tratar sobre obras de arte, livros e cartazes, nos inserem no universo da política, cultura e outras formas de relações sociais de um jeito interessante. As peculiaridades das minúcias adentradas pelo olhar do autor provocam no leitor imaginações intensas, e nos faz conhecer um dado período histórico por meio da arte. Além de realçar os aspectos que muitas vezes são negligenciados pelos olhares imediatistas e despretensiosos.

À vista disso, Ginzburg nos lembra de que "para compreender o presente, devemos aprender a olhá-lo de esguelho" (GINZBURG, 2014, p.13). Ou seja, além de tomarmos como elemento construtor das correlações que potencializam a dinâmica de cada momento histórico, faz-se necessário lembrar que as ações dos sujeitos, os movimentos e relações próprias de cada momento servem de porta de entrada para outras conjunções de forças passíveis de leituras nas suas entrelinhas.

Como exemplo, cito Guernica, de 1937, do pintor Espanhol Pablo Picasso. Essa obra de arte, talvez a mais documentada do Ocidente, representa o bombardeio do pequeno povoado basco localizado na Espanha. Foi palco de disputas entre a União Soviética de um lado, e Alemanha e Itália do outro lado. Francisco Franco liderou a insurgência do exército e contava com o apoio dos últimos.

A história da guerra civil na Espanha (1936-1939) foi, e ainda é documentada por vários livros que retratam aqueles tensos e bárbaros eventos que resultaram na morte de civis. Todavia, podemos de igual maneira nos apropriar das imagens para estudar esse recorte histórico a partir de observações estruturadas num aporte iconográfico.

As várias possibilidades de leitura iconográfica que podemos fazer de Guernica, pensada aqui como um exemplo preliminar de uma arte Moderna, que realça e alicerça uma série de questões que serão problematizadas mais adiante. Todavia, todos os traços e símbolos presentes na obra dimensionam o entrecruzamento dos vetores que embasam um estudo acerca de um estudo minucioso dos elementos ali presentes, como nos faz refletir a partir daí: a política, a economia, as relações sociais, a cultura, os poderes, etc.

Logo, o processo de construção de Guernica, que é uma das obras mais lidas e estudadas na arte Moderna, ganha destaque naquilo que se pretende conhecer sobre a dinâmica de uma narrativa extremamente tensa e perversa. Entre outras coisas, Picasso buscou representação no período clássico e na mitologia Grega. Contudo, nos interessa aqui fazer algumas considerações acerca de alguns elementos substanciosos, de forma que possamos abrir caminho para a definição do conceito, assim como tratá-lo na perspectiva da "leitura iconográfica na modernidade". 
Figura 01: Guernica

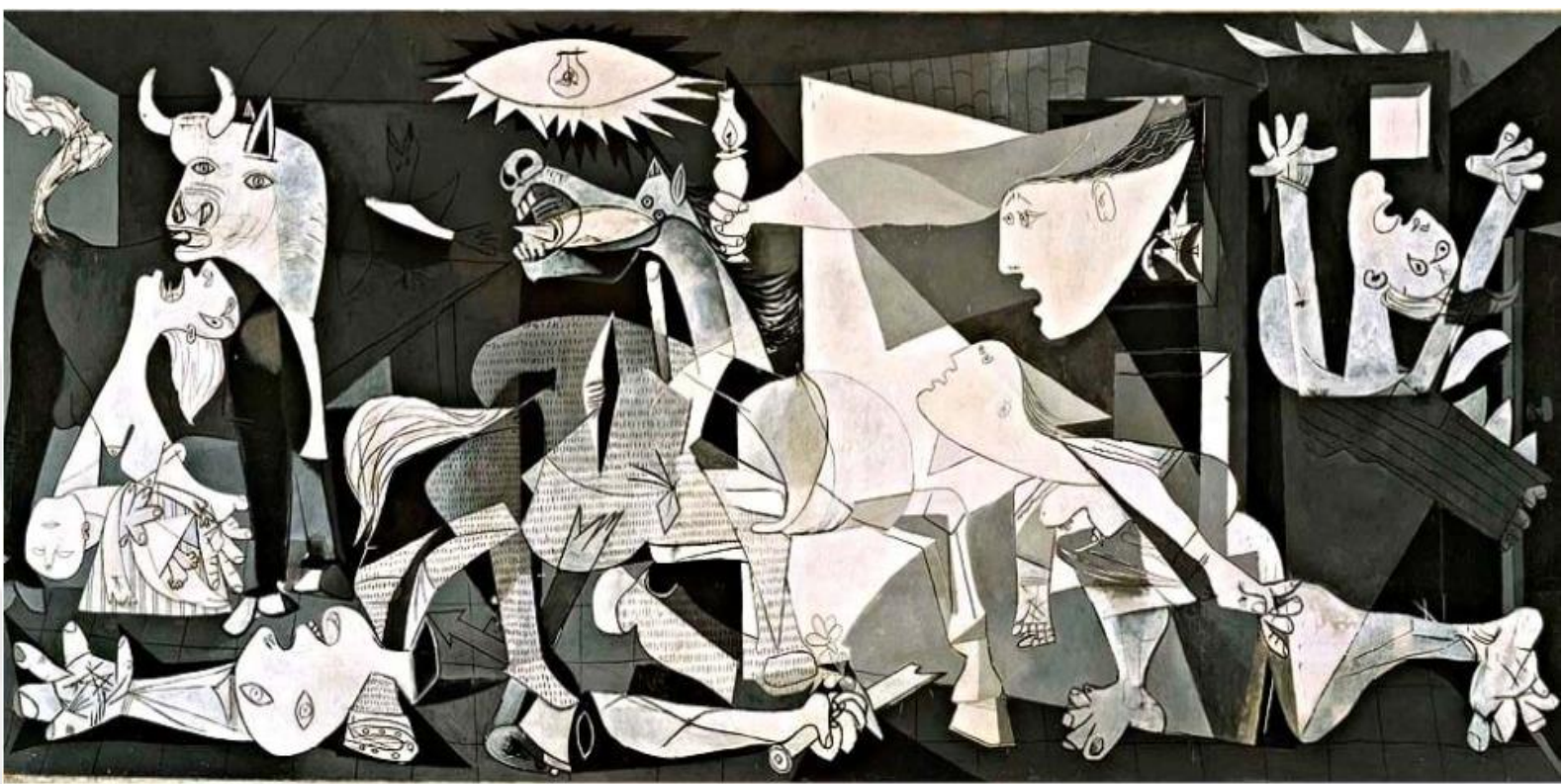

Fonte: PICASSO, 1937

https://www.sabado.pt/gps/arte/detalhe/guernica-o-quadro-que-lutou-contra-o-fascismo-faz-80-anos. acesso em: 07 de março de 2021.

O nome da obra faz menção a um pequeno povoado da Espanha, localizado numa região basca. Os bombardeios se deram em 26 de abril de 1937, tendo como os principais atores dos ataques as tropas do Nazismo e do Fascismo. Por isso, "Picasso teria investido não somente contra o fascismo, mas contra o totalitarismo em geral” (GINZBURG, 2017, p. 104). Logo, é possível perceber que na obra existem algumas referências à terra natal do autor. O caminho traçado para a realização das pinturas nos diz muito sobre as tensões vividas pelos que estavam inseridos numa luta permeada pelas disputas ideológicas. Assim como os elementos presentes no quadro tem significados claros sobre o mundo que os cercavam. Com o processo de confecção não era diferente. Como o próprio autor diz:

No passado, os quadros avançaram para o término por estágio. Cada dia trazia algo novo. Um quadro era a soma de acréscimos. Em meu caso, um quadro é uma soma de destruição. Faço um quadro, depois o destruo (Ginzburg. 2017, p. 116).

Essa "destruição" apontada por Picasso pode ser entendida de maneira que o Moderno implica em mudanças rápidas, impondo para o artista mudar os rumos de seu projeto, porém mantendo a essência de seu esboço. Esboço esse muito utilizado pelo autor e transformado ao longo de sua execução.

Quando Picasso recebeu a notícia do ataque à Guernica, estava na França, no seu estúdio. Enquanto ao quadro propriamente dito, é possível ver alguns riscos, pequenos traços, quase 
imperceptíveis. Uma das versões é que eles representam a quantidades de vítimas do ataque. A outra tese é a de que o autor teria colocado alguns jornais no fundo da tela, e em seguida iniciado a pintura, evidenciando assim as pequenas letras. Um ponto importante para que possamos entender a Guernica, entre outras obras de Picasso, é que o autor ressignifica algumas obras ou simbologias gregas. Quando as insere na Modernidade, para falar sobre a dinâmica da Modernidade. O cavalo alado, Pégaso, representa a força e perseverança dos civis naqueles tensos dias. Ou seja, isso é uma representação, uma soma de símbolos que surgem na pintura.

A mulher que aparece do lado esquerdo da tela segurando uma criança morta nos braços, com expressão de angústia e sofrimento, representa, além das pessoas vitimadas pelas atrocidades daquele bombardeio, todos os que sofreram pela existência e perseguição do sistema totalitário.

Em síntese, Guernica se tornou uma obra de representação política e combate ao totalitarismo. Atravessou o tempo, mas sua interpretação, mesmo contendo os elementos daquela temporalidade, não permanece estanque, pois os caminhos a serem desvendados ainda são múltiplos. Ainda hoje é factível suas injunções atemporais da violência e das barbáries que ameaçam as democracias. Todavia, o objetivo de tratar sobre essa obra de arte como exemplo de um estudo iconográfico, não significa que as pretensões aqui foram elencar todos os elementos contidos no quadro, mas, sim, introduzir neste trabalho um caminho para a leitura iconográfica das imagens na Modernidade. E que servirá de vértice para o estudo cinematográfico tecido a partir de agora.

\section{O TEMPO COMO CONSEQUÊNCIA DA MODERNIDADE E SUA REPRESENTAÇÃO NO CINEMA.}

A partir das ponderações acerca do que determinou a lógica que triunfou nas relações sociais com o avanço do capitalismo, percebemos que este, paulatinamente, passa de comercial para um formato mais arrojado, que é o industrial, sobretudo com o aperfeiçoamento das técnicas desenvolvidas pela burguesia local. Dessa maneira, o controle do tempo, que não foi uma criação da modernidade, mas que foi reconfigurado por esta, e que agora passa a ganhar uma nova importância com a chegada desta classe. E se torna fator preponderante e central para a dinamização no processo de urbanização.

Os movimentos passaram a ser normatizados, pensados, racionalizados e condicionados por esse novo formato do viver em sociedade. De maneira que tal ritmo foi percebido e retratado pela arte para caracterizar essa conjuntura pujante, mas que se mostrava contraditória na sua 
operacionalização. Contudo, uma nova forma se moldava para se contrapor ao fator "harmônico" desse período, que podemos apontar como sendo atravessadas por tensões oriundas das classes que eram incessantemente exploradas. As ferramentas de combate, assim como os múltiplos entrelaçamentos de resistências, foram pensadas a partir da arte como um mecanismo de profusão cultural, que comunicou e denunciou os momentos que se prenunciavam.

O fator tempo é apresentado como porta de entrada para alguns clássicos do cinema, objetivando-se, entre outras coisas, tecer a lógica que permeou a dinâmica do período marcado pelas rápidas transformações que determinaram profundamente o avanço dos modos e relações de trabalho que agora emergem sob a égide do capital industrial.

O Moderno, portanto, foi definido por este caráter dissoluto em que o homem agora passou a vivenciar. Pois as relações doravante são colocadas à prova por esses constantes ritmos impostos de maneira veloz e avassaladora. $\mathrm{O}$ homem se torna um apêndice dessa nova realidade, pois o tempo triunfa na vida cotidiana, reconfigura e ordena os diversos meios de atividade laboral, como decreta hábitos e costumes a serem seguidos. A herança dessas investidas foi sobremaneira capturada pelas artes, nesse caso o cinema, que se debruçou nessa emergente e nova configuração mundial, e procurou retratar suas nuances, como buscou por meio da transgressão, subverter aquilo que era posto como forma de domínio.

Com isso, pensar a História a partir de um prisma onde apenas houve dominadores e pessoas submissas e fracas, é negar os fatos preponderantes e a essência dos que lutaram. Quando aponto a importância de entendermos o Marginal na História e suas condutas no cotidiano, com fortes conotações para aquilo que pende para os pequenos detalhes, coloco a ideia de que é nas margens que a História se faz compreendida na sua completude, até mesmo para pensar o sistema de contradição que se entrelaçam nos centros dos acontecimentos. São nas bordas que as pistas são evidenciadas.

Nessa perspectiva, tratar sobre o tempo e a maneira como ele foi concebido e representado pela arte cinematográfica, e retratar os impactos diretos do processo modernizador, é historicizar os acontecimentos. É, também, problematizar sobre esses sujeitos "esquecidos". Entretanto, esses fatores podem ser lidos iconograficamente.

Entre os filmes que abordam o tempo como mensagem metafórica dessa relação, citamos aqui, a título de exemplo, dois clássicos do cinema mundial. A saber: Metropolis, filme alemão lançado em 1927 pelo austríaco Fritz Lang, e Tempos Modernos, filme americano lançado por Charlie Chaplin, em 1936. Ambos trazem, entre outros elementos importantes para a presente análise: como a questão da relação produtiva, impulsionada pelo capitalismo industrial, e controlada a todo o momento pelo 
tempo, tornou-se parte integrante desta constituição. Mostram a forma como se estruturam essas correlações de forças essencialmente capitalistas, que remontam às revoluções e que, de certo modo, empregaram uma nova dinamização para melhor compreendermos o metabolismo social vigente.

Quero colocar com isso que os possíveis caminhos que nos guiam até os traços e pontos iconográficos daquela conjuntura, momento de suas atividades laborais, nos direcionam para um universo já em colapso, e que o sentido do condicionamento daquilo que se convencionou chamar de moderno, passava pela retirada da essência humana, ou pelo menos criar certos controles sobre suas ações, no sentido aqui de torná-lo subalterno das atividades realizadas de modo incessante pelos operários. Ou seja, a modernização condizia com o fato de tornar todo e qualquer movimento desprovido de autonomia. Todavia, fica claro que há nessa correlação de forças o vértice da história urbana, na qual a arte e os sujeitos que dela se apropriaram emergem como transgressores deste universo desfigurado, de modo que a cidade passa a ser reivindicada como lugar das práticas sociais, como a própria arte e outras manifestações.

O objetivo aqui, portanto, não é tratar incessantemente dos filmes acima mencionados, de modo a esgotar todas as informações contidas nas obras descritas, mas, sim, trazê-los como suporte para o escopo aqui desenvolvido, de maneira a esquadrinhar os momentos que realçam os pontos centrais para que eu possa discorrer sobre a temática intrínseca ao período que dará sustentação para a emergência e pano de fundo da cinematografia, o que considero importante para minha fundamentação teórica. O tempo condiciona esse pano de fundo em algumas obras. Como a representação do relógio, já no início do filme Tempos Modernos (1936).

Figura 02: O tempo como substância da Modernidade

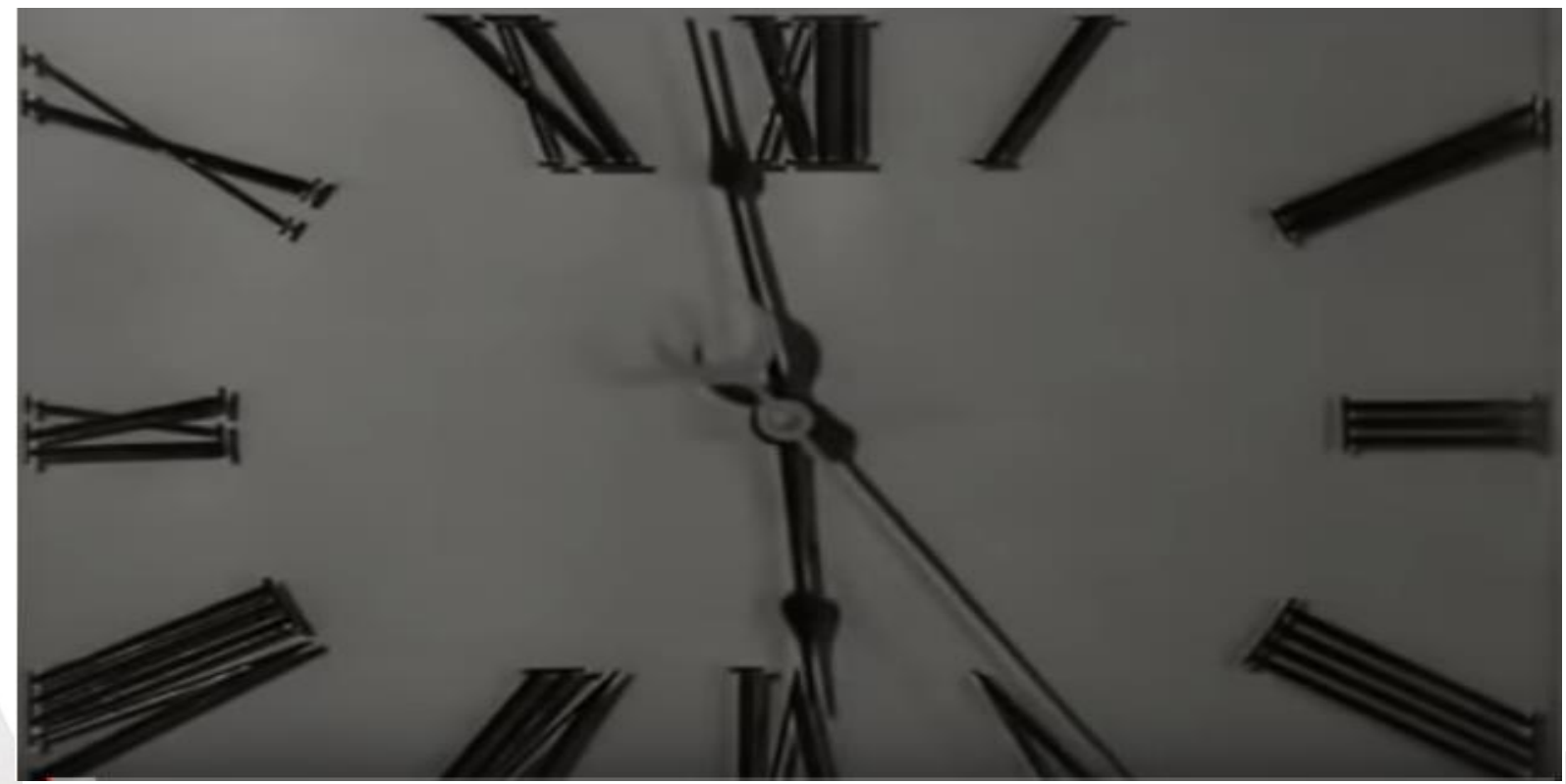


Fonte: Tempos Modernos, 1936. Direção: Charles Chaplin

Constata-se que a aparição do relógio (fig. 02), que metaforicamente emerge no início do filme, Tempos Modernos, restando poucos segundos para cravar as 6 h00 da manhã, seguidos de imagens de uma multidão de operários entrando nas fábricas, é o presságio do que viria nas cenas subsequentes. Nesse ínterim, todos realizam movimentos frenéticos, e ao mesmo tempo harmônicos. Dirigem-se para o mesmo lugar, seus postos de trabalho, para mais um dia extenuante e paranoico em suas intensas produções, que embrenhados nos ritmos alucinantes impostos pelas máquinas e a perversidade da busca diária por metas, alimentam a organicidade desse sistema bárbaro e voraz.

Logo, o fator tempo, representado por esse relógio mecânico, é parte orgânica dessa costura de acontecimentos. Com isso, é possível constatar que algumas realizações fílmicas pouco depois de sua invenção e aperfeiçoamento já se debruçaram nas temáticas que faziam parte do cotidiano das pessoas, assim como buscavam traçar como método de compreensão daqueles momentos: a captura dos fazeres do dia-dia. Quando aparece o relógio no filme, uma música frenética sincroniza-se com os movimentos dos ponteiros, e logo em seguida por uma sequência de imagens: as ovelhas, depois os operários. Esse plano-sequência é consolidado, nesse instante, por uma voz que abre o filme e profere a seguinte frase: "a humanidade em busca da felicidade".

Figura 3: Ovelhas num caminhar frenético

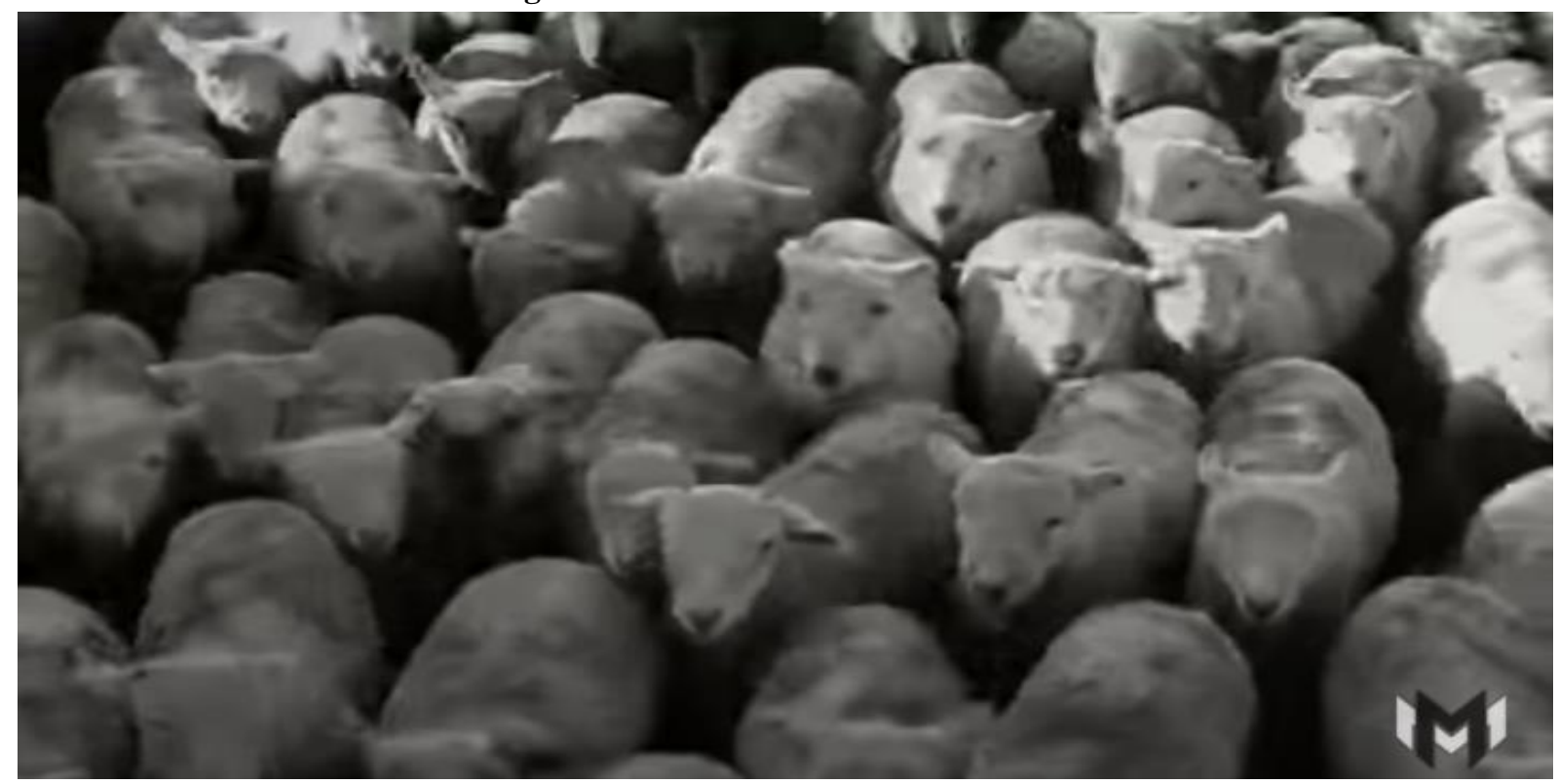

Fonte: Tempos Modernos, 1936. Direção: Charles Chaplin. 
Figura 4: Operários a caminho da fábrica.

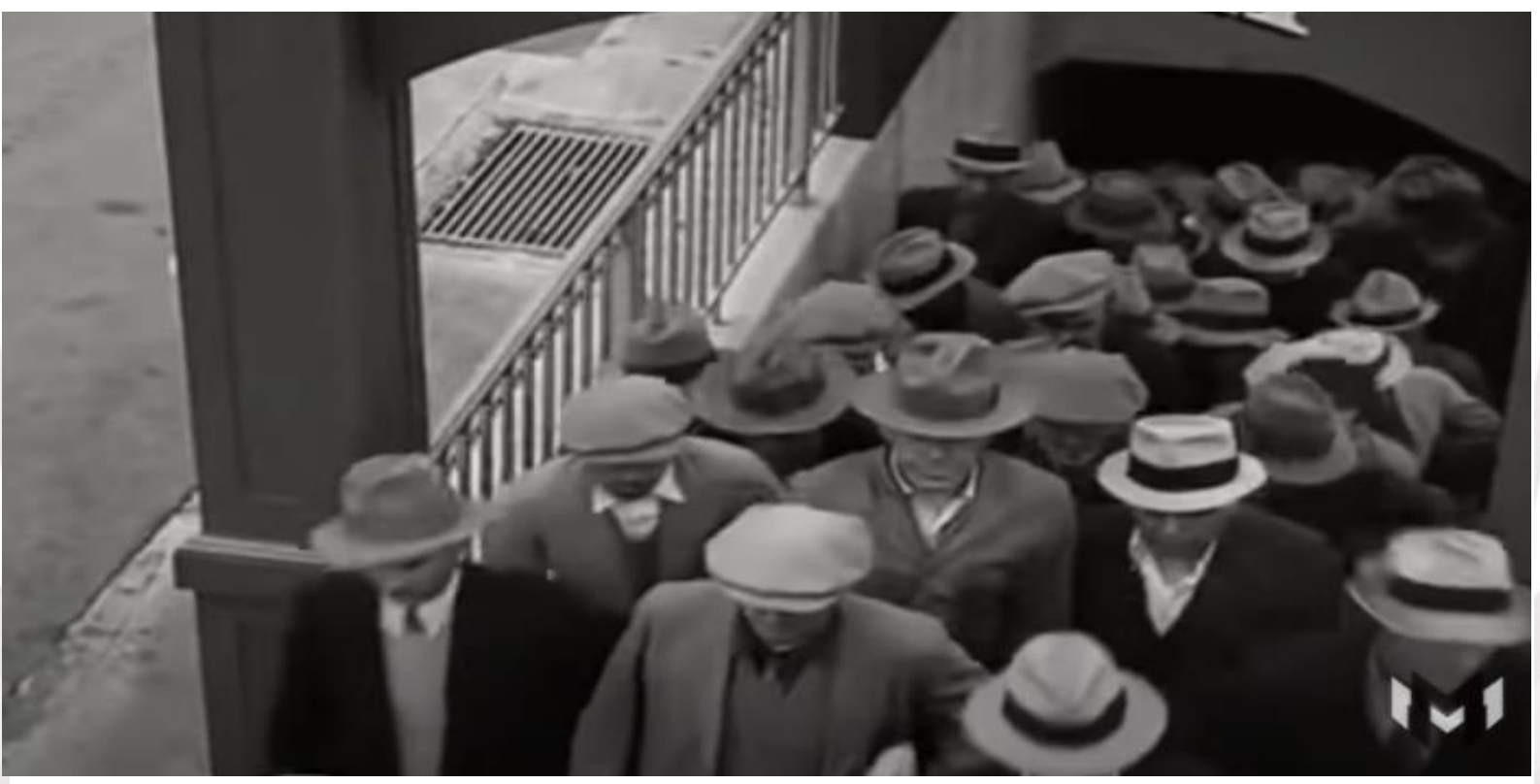

Fonte: Tempos Modernos, 1936. Direção: Charles Chaplin.

Podemos abstrair inicialmente desses recortes algumas questões que pressagiam a obra, como as metáforas que atravessaram todo o filme. Quando a voz off diz que a humanidade busca a felicidade, em seguida temos um corte para as ovelhas que entram em cena. São impulsionadas pelo movimento compulsório da multidão. Cabeças erguidas e movimentos mecânicos. Corte: os operários têm seus olhares parcialmente encobertos pelos chapéus, mas o deslocamento sincronizado dos movimentos, apontam para um chão que certamente dará em algum lugar, possivelmente seus postos de trabalho. Fica evidente que os movimentos e pretensões da humanidade nessa busca incessante pela felicidade são satirizados por Chaplin como um preceito utópico. Um animal tem suas ações movidas por instintos, são irracionais. Enquanto o homem tem seus movimentos conduzidos por propósitos construídos com base numa modernidade que avança e reconfigura cada vez mais aquele período histórico. A lógica daquele sistema é o de enquadrar e normatizar os corpos e mentes.

Ambas as imagens, extraídas de Tempos Modernos, assim como outras de igual importância, podem ser decupadas de modo que o sentido da fala seja esquadrinhada. Os movimentos e gestos dos animais e homens que surgem nas cenas passam a nos dizer algo sobre as relações sociais que permeiam aquela sociedade. Os mais suscetíveis detalhes servem de vestígio para uma investigação e indícios que nos conduzem para tantas outras performances daquela dinâmica. Mais adiante há outra imagem clássica que simboliza esse período: a máquina engolindo o operário. 
Figura 5: homem nas engrenagens

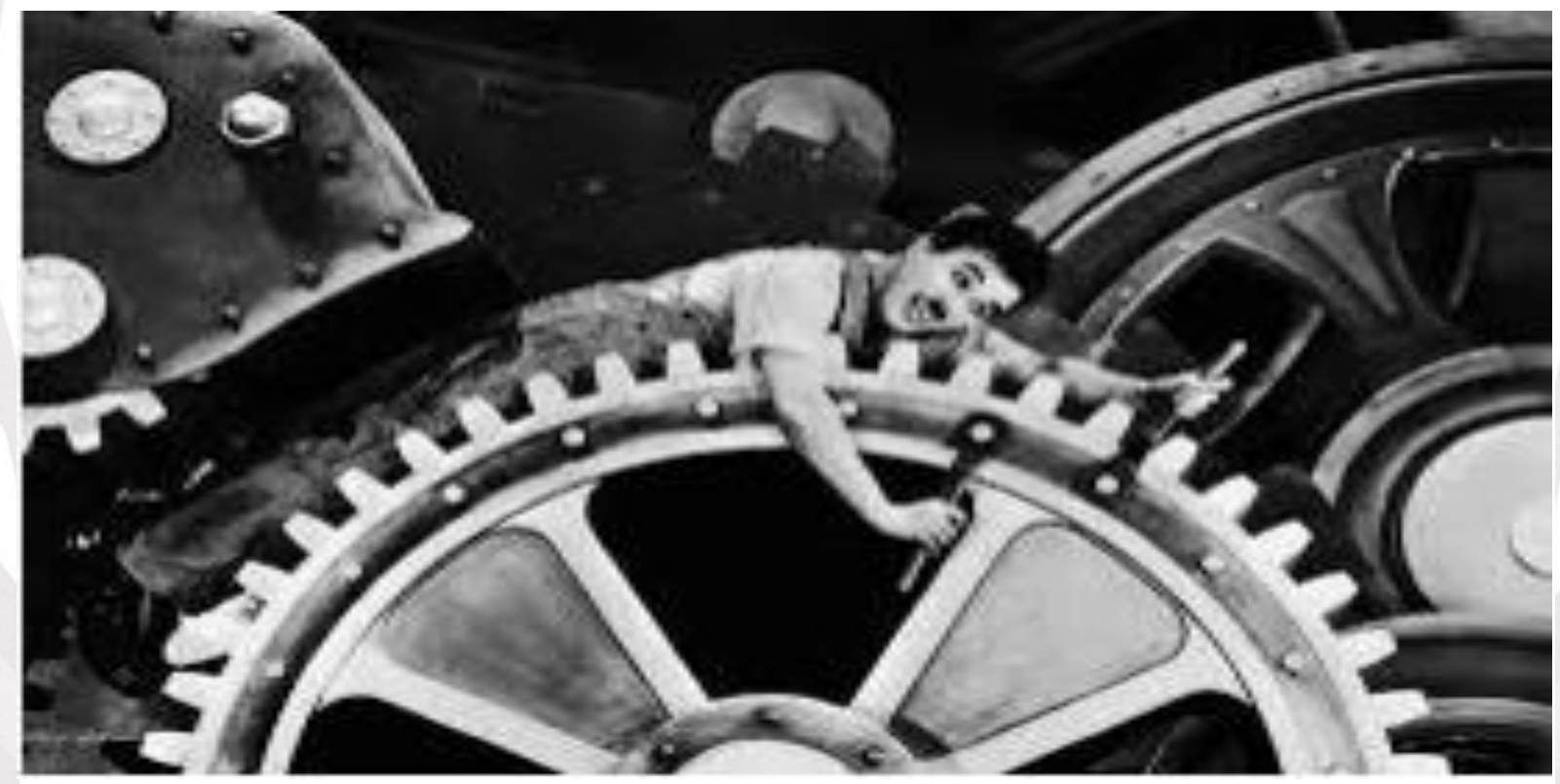

Fonte: Tempos Modernos, 1936. Direção: Charles Chaplin

Nessa costura de acontecimentos, Tempos Modernos se caracteriza pela inserção das

máquinas, e mais adiante da tecnologia na vida das pessoas, além de expor as vísceras de um mundo dentro e fora das fábricas. Nessa imagem (fig. 5), àquela altura, o objetivo é problematizar a maneira como a máquina "engole" o homem. Essa é outra metáfora que sistematicamente representa as consequências da etapa do capitalismo industrial, onde já se priorizava essas sólidas estruturas de confecção, sob o controle do tempo como substância dessa nova engrenagem social, que consequentemente possibilitaria o lucro.

Com base no exposto, podemos afirmar que essas questões passaram a se tornar comuns, sobretudo através das manifestações artísticas, devido à sintonia com os termos e normatizações trazidas do passado e concretizados na conjuntura atual, na qual o mundo vivia. Mesmo que àquela altura seus idealizadores talvez não estivessem com o objetivo de evidenciar o mundo a partir de seus descompassos, fragmentações e dissonâncias. Contudo, as produções atravessaram as fronteiras e o tempo. Refiro-me a tais filmes como forma de realçar os elementos que expõem as práticas sociais inerentes àquele recorte temporal.

Ao historiador é possível buscar esses traços reveladores, como constatar as formas como essas mudanças passaram a fazer parte da relação social, e, por conseguinte, como isso se estendeu para outros lugares. Ou seja, é factível analisar o filme como campo de possibilidades, como o fato de compreender o mundo em que esse foi realizado, suas práticas, os sujeitos presentes nessa 
dinâmica, assim por diante. A obra fílmica, nesse caso, é posta como um documento histórico passível de análises acerca de um período revelador de suas tensões.

O filme traz uma série de elementos que se entrecruzam naquela realidade. Um metabolismo todo costurado pelo autor de modo a satirizar as inconsistências ali presentes. Contudo, iremos nos deter em apenas uma das vertentes ali estabelecidas para ilustrar o aspecto aqui levantado, que é o tempo como substância dessa composição Moderna.

A obra tem como premissa básica, entre outros pontos de igual importância, discorrer sobre as fragilidades contidas naquele modo laboral que se vigorava. E que se configurou como uma crítica feita por Chaplin ao sistema Taylorista-fordista ${ }^{65}$ de produção, posto como as novas performances da gerência e organização fabril. Essas etapas foram pensadas por diversos autores, que podem dar conta de explicar de forma mais profunda sobre tal feito, assim como suas consequências.

Outro ponto a ser notado é justamente o das consequências do que foi projetado com a Revolução Industrial, além das investidas que desembocaram nas transformações tecnológicas e científicas do século XIX, sobretudo com o advento da eletricidade, como já apontado.

Observa-se que o tempo, esse fator preponderante e central para melhor compreensão daquela atmosfera, atravessa toda a filmografia, como se toda a sociedade estivesse imbuída nessa substância aperfeiçoada pelo capitalismo. E de fato estava. Pois toda a dinâmica dentro e fora da fábrica chamava atenção para uma coisa: os movimentos pensados a partir da sincronização dos ponteiros do relógio, como uma conduta regida pelo objetivo de chegar a um lugar previamente determinado. O filme, portanto, é uma forte crítica a esse novo mundo do trabalho que não se sustentava na sua imediaticidade, mas que deixava transparecer seu caráter fugaz de uma realidade Anômica. ${ }^{76}$ Os movimentos repetitivos deixaram sequelas não somente no corpo, mas na parte psicológica. As críticas direcionaram-se para esse novo formato de gerenciamento do trabalho.

Ainda sobre os aspectos da Modernidade, que impactaram a sociedade da época, e que foram representados pelas filmografias, temos ainda o filme de Fritz Lang, Metropolis (1927), que pode ser compreendido como condutor de outras temáticas pertinentes ao processo de urbanização e alteração

\footnotetext{
${ }^{65}$ A Organização do Trabalho do Século XX que inseriu o método taylorismo, fordismo e Toyotismo, evidencia as transformações, também, do comportamento do sujeito. Embora este modo de produção não trate especificamente sobre tudo o que aparece no filme Tempos Modernos, de Chaplin, mas pode nos auxiliar no entendimento do que foram as formas de organização do trabalho no final do século XIX pro XX, assim como situar o leitor acerca das perspectivas daquele momento. Além disso, traz alguns elementos constituídos como consequência da Modernidade, impondo de forma direta, para o homem, o condicionamento padrão instituído pela lógica capitalista, visando o lucro das corporações. Ver: PINTO (2007).

${ }^{76}$ Termo usado pelo sociólogo francês Émile Durkheim (1858-1917), que se refere a uma sociedade com falta de coesão social, em outras palavras, uma sociedade em crise, em vias de colapso. Ver: QUINTANEIRO; BARBOSA; OLIVEIRA (2009).
} 
de tempo-espaço, assim como a apresentação das consequentes transformações no campo social. O filme mostra a parte de cima da cidade, habitada por uma classe que detém os meios de produção. E a parte de baixo, o subterrâneo, onde os operários executam suas atividades incessantemente para alimentar e manter os privilégios da parte de cima. Entre outras temáticas suscitadas pelo filme, temos A Luta de Classes (JOHNSON, 1997. p.47). A leitura iconográfica consiste, entre outros pontos de igual magnitude, na observação das ações, cenários, falas, máquinas, e as tensas relações entre as classes sociais presentes durante a obra.

Figura 06: A robotização humana

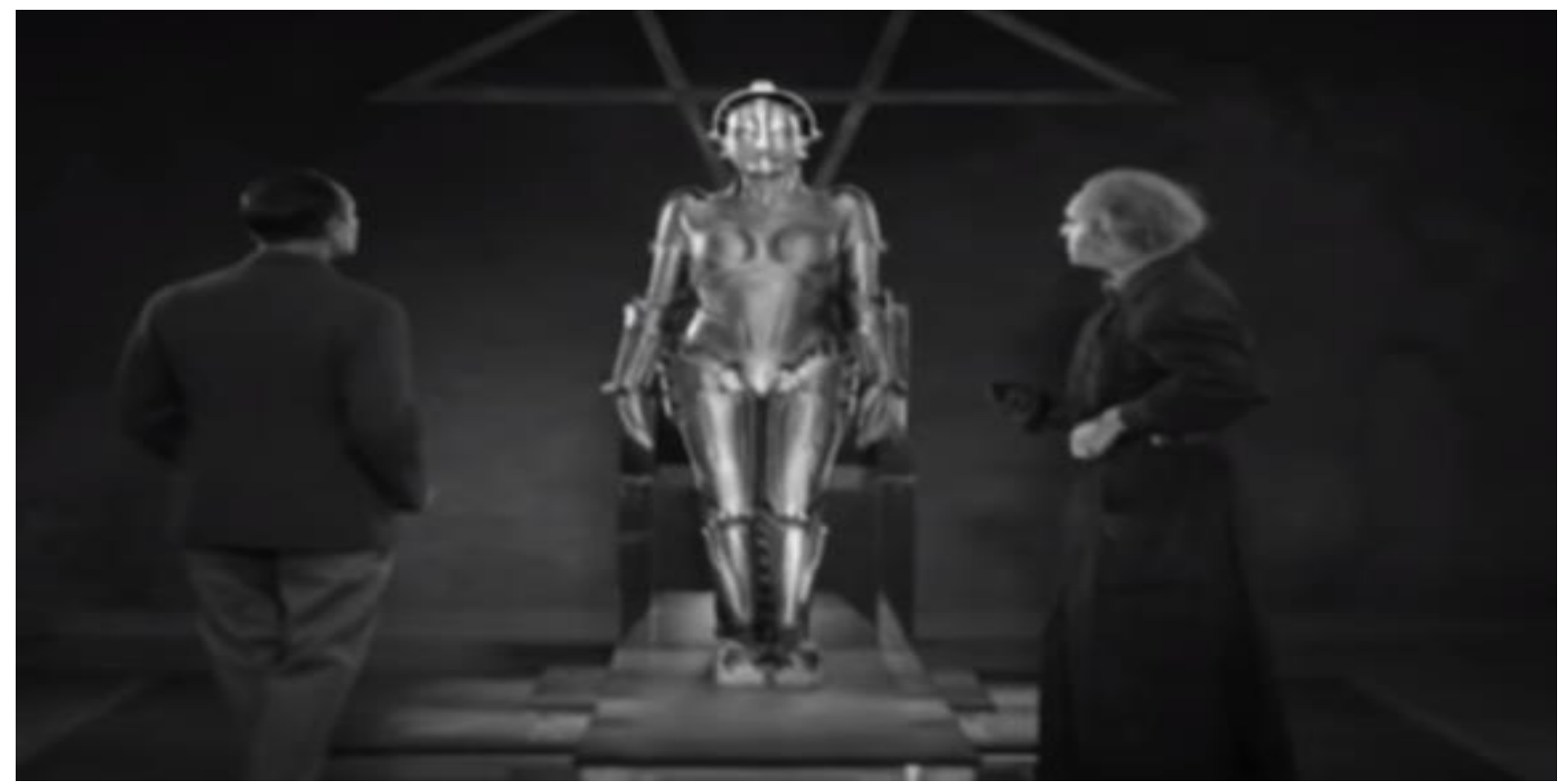

Fonte: Metropolis, 1927. Direção: 
Figura 07: A cidade verticalizada

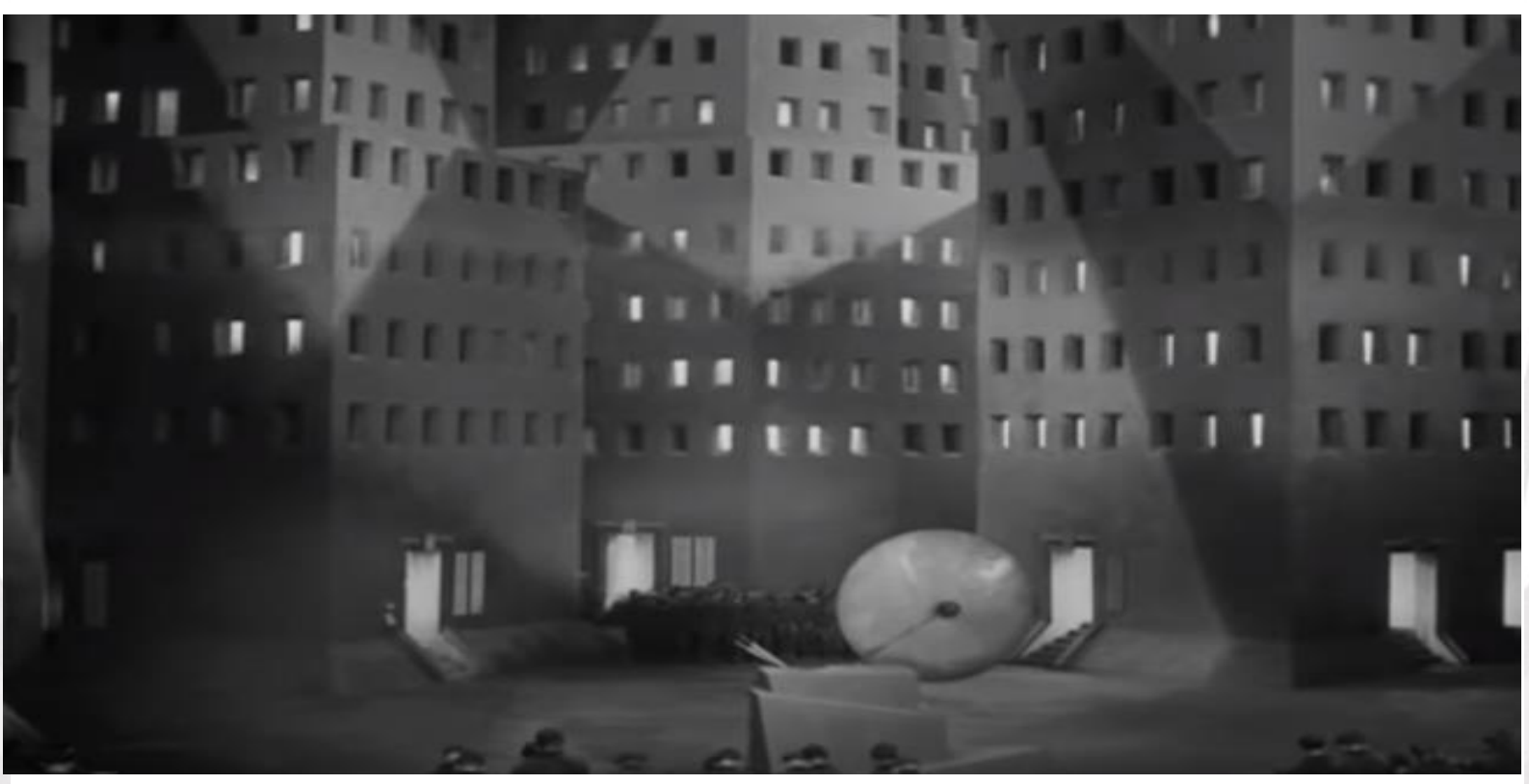

Fonte: Filme Metropolis, 1927. Direção:

O prognóstico de uma cidade regida pelo metabolismo mecânico, como os apresentados acima (figuras 06 e 07), nos remete ao mundo desconexo e fugaz condicionado pelas incessantes transformações. As imagens preliminares do filme nos levam a fazer prognósticos, além de fazer algumas observações iconográficas necessárias para compreendermos a verticalização do que hoje assimilamos como uma "selva de pedras", operados pelos movimentos mecânicos e robotizados do homem. O robô simboliza o controle de uma classe para com a outra, é sistematicamente observado e pensado para que os comandos atendam as expectativas de produção, além da tentativa de refutar qualquer tipo de subversão e greve. Os prédios imponentes e iluminados personificam a desigualdade social, denotam de igual maneira a estratificação e divisão social presentes em Metropolis. Abaixo dali existe um mundo subterrâneo, a classe que alimenta e sustenta essa estrutura.

Ismail Xavier nos lembra de que a funcionalidade de Metropolis, além das descrições sintomáticas que caracterizam a dinamização urbana, nos possibilita trazer para a superfície das discussões alguns temas articulados a essas rápidas mudanças, na medida em que constatamos uma sociedade altamente fragmentada, como evidenciando de maneira clara o abismo social entre elas. Ainda sobre isso, Ismail coloca que:

Desde a abertura, o filme destaca a cidade-fábrica, unidade produtiva que, curiosamente, embora suponha outras atividades, configura-se diante de nós como cidade-monumento, estrutura que se esgota em si mesmo [...] Já observei o quanto 
há uma sintomática ausência de circulação, de um dinamismo urbano (XAVIER, 2011, p. 31)

Podemos notar que esse roteiro de consolidação urbana constatada na cidade-fábrica de Metropolis não pressupõe algo dinâmico, nem aberto, com possibilidades de circulação, uma das teses defendidas por Ismail no trecho acima. Ainda sobre esse conceito, podemos defini-lo como a maneira que a cidade é condicionada como espaço de produtividade, projetada e desenvolvida para o trabalho.

A justaposição dessas palavras é o que define aquela atmosfera, onde a circularidade de pessoas e ideias é reduzida a um mecanismo de movimento mecânico enquadrado para/na unidade produtiva. As circularidades, podemos colocar assim, estão restritas aos materiais e pessoas que habitam a parte de cima. O subterrâneo, aqui entendido como a parte baixa onde as pessoas transitam, é condicionado pela supressão das elites detentoras dos meios que geram a riqueza. O que nos faz olhar com atenção para a estrutura hierárquica em que aquelas pessoas vivem, como exemplo da cidade verticalizada acima. O tempo aparece mais uma vez como ponto intrinsecamente ligado à modernidade, pois o forte controle sobre os corpos é sistematicamente marcado pela lógica de abastecimento da parte alta da cidade, onde mora a elite.

Observa-se que esse forte controle sobre os corpos, a maneira como a classe dominante procura construir um poder frente a essa tentativa de normatização das ações e condutas desses sujeitos, não está restrito a esse período, e não se reduz ao processo de inserção desses ao âmbito do trabalho. Ou seja, foram construídos mediante a constante estigmatização, segregação e marginalização.

Outro vértice importante nessa lógica construtiva do que veio a ser esse processo de urbanização, é a criação e/ou aperfeiçoamento das técnicas que emergiram no decorrer do século XVIII, e que vão culminar naquilo que caracterizou a "velocidade" contida nos fazeres do cotidiano.

O cinema que surge no final do século XIX, mais precisamente em 1895, retrata as questões que permearam todo aquele século, além de capturar as simbologias condizentes com aquele momento, como é o caso da eletricidade, do trem, das fábricas e seus trabalhadores, entre outros pontos pertinentes ao que pretendiam os idealizadores da arte cinematográfica àquela altura. E que, portanto, todos passíveis de uma leitura iconográfica.

O Moderno foi marcado, entre outras coisas, pela intensificação da velocidade, onde o tempo foi substancialmente colocado como força motriz dos deslocamentos, seja de pessoas e/ou de objetos por eles criados. O que implicava, sobremaneira, em outras questões concernentes aos costumes 
diários. Isso fica perceptível nas intensas invenções ou aperfeiçoamentos dessas ao longo dos anos posteriores à Revolução Industrial. Ou seja, as máquinas ganham novas funcionalidades, de maneira que o homem, na maioria das vezes, torna-se apêndice de um instrumento que, outrora, detinha controle. A lógica dessa intensificação passa pela compactação das mudanças triviais nos hábitos e costumes dos grupos presentes nessa nova configuração.

Todavia, os primeiros filmes da História do cinema retrataram essa temática, tanto do trem como meio de transporte da época, força motora das conexões entre regiões distantes, que além de ser visto como veículo de transporte de mercadorias, de igual maneira era percebido como o símbolo daquele tempo, integrador de regiões até então distantes.

No filme A Chegada de um Trem na Estação, de 1895, com tempo de duração de aproximadamente um minuto, os Irmãos Lumière nos apresentam uma película em plano fixo, tido como o primeiro filme da História, projetado em uma sala para alguns convidados, que segundo os relatos daquele dia, se assustaram com a rápida aproximação do trem que parecia ir à direção da plateia, causando assim um alvoroço.

O que nos interessa nessa questão é estabelecer um diálogo com aquilo que simbolizava o trem, pois a solidificação que dinamizava a cidade como um campo de transformação, que simbioticamente pulsava em meio a um tenso e paradoxo período histórico, já há muito se constituía. O cinema apenas buscou suas referências para caracterizar sua organicidade: como o modo de funcionar naquela sociedade. Entretanto, a compreensão do filme consiste em atrelá-lo a um recorte em que foi realizado, para, entre outras coisas, entendermos as práticas comuns em meio aos sujeitos, assim como ler seu contexto, levando em consideração sua temporalidade.

As obras fílmicas aqui descritas são elucidativas, uma vez que estão inseridas nesse processo de maior compreensão para o que foi estabelecido como critério de análise no artigo, que é pensar o cinema como consequência dos movimentos que convergiram para o desencadeamento da Modernidade. Além do que, levando em consideração os vários pontos aqui realçados, o filme pode ser usado como um documento histórico, alicerçado em uma série de elementos concernentes a uma determinada conjuntura.

Nessa perspectiva, fazem-se importantes algumas ponderações acerca dos múltiplos direcionamentos para se buscar nas filmografias seu papel elucidativo de uma época. Contudo, para estudar um filme, bem como outras obras de arte, é necessário esquadrinhá-lo de forma cautelosa, de maneira a revelar os pontos implícitos e, por conseguinte, trazer à tona a conjuntura na qual a obra 
foi realizada. Assim como estabelecer um constante diálogo com outros fatores de igual importância que dizem muito sobre suas facetas. A saber: as relações sociais, econômicas, políticas e culturais.

Para Marcos Napolitano (2011), o filme é um documento histórico de sua época. Dessa forma, todo historiador que se voltar para tais estudos, tendo como objetivo compreender a sociedade de uma determinada época, mediante a análise de uma produção fílmica, tem de levar em consideração a historicidade que o momento carrega. O que significa ler nas entrelinhas aquilo que muitas vezes os documentos escritos não registraram e/ou deixaram para um segundo plano. Sua problemática é transportada para um campo onde as possibilidades de análises subvertem os olhares imediatistas e despretensiosos.

Podemos, com isso, dimensionar que a inserção de máquinas e novas atividades, como critério norteador de um dado período, assim como o tratamento das matérias-primas a partir dessa conjuntura, além da emergência de organizações em torno da ideia de trabalho, são sustentados agora em métodos racionalizados ${ }^{87}$. O que pressupõe o aperfeiçoamento das técnicas no ambiente fabril, assim como esse elemento passa a fazer parte da vida cotidiana das pessoas.

Ainda no que toca às questões pertinentes ao campo do desenvolvimento industrial, como período marcante para as transformações correlacionadas ao Urbano, e, por conseguinte, do cinema, o Sociólogo britânico Anthony Giddens nos lembra de alguns pontos que caracterizam a Modernidade:

Umas das características mais óbvias que separa a era moderna de qualquer período anterior é seu extremo dinamismo. O mundo moderno é um "mundo em disparada": não só o ritmo da mudança social é muito mais rápido que em qualquer sistema anterior; também a amplitude e a profundidade com que ela afeta práticas sociais e modos de comportamento preexistentes são maiores (GIDDENS, 2002, p. 22)

Vislumbro com isso que, o conjunto de transformações atreladas às grandes descobertas revolucionárias marcou profundamente esse período, o que deu maior amplitude aos pontos norteadores que configuraram as relações sociais até então presentes. A Modernidade impôs uma série de desafios, como a alteração das relações e comportamentos de homens e mulheres.

\footnotetext{
${ }^{87}$ Conceito empregado por Max Weber para designar, a princípio, uma sociedade já no seu estágio complexo, onde a vida
} social passaria a ser regida por cálculos racionais, voltado para a produção. Ver: JOHNSON (1997). 
A capacidade de alcance dessa necessidade moderna foi marcada pelo envolvimento de várias culturas, ou seja, os comportamentos que antecederam esse novo formato passaram, a partir de sua dinamização, a fazer parte desse processo. Quero dizer que o tempo aqui emerge como substância dessa modernidade e caracteriza as relações de um período extremamente diligente na sua performática narrativa, que por certo evidenciou algumas inconsistências de uma estrutura que ganhava cada vez mais um corpo notabilizado pelas imperfeições estruturantes.

Como Giddens (2002, p. xx) mesmo coloca, a "separação de tempo e espaço" é explicada pelas necessidades que os vários povos vivenciaram, como numa conexão necessária à sobrevivência.

As consequências dessas mudanças se fizeram presentes no campo da arte e na reivindicação desta por sujeitos, que ocupando as bordas das cidades, protestaram fazendo uso das próprias ferramentas criadas pelo sistema. Dessa maneira, a máxima de que o sistema se afirma na negação desses marginais, encontra um ponto que converge para a retomada dos espaços para a prática de resistência, ou seja, ao negar e/ou refutar os que não se enquadram nos padrões estabelecidos pela sociedade de cada época. O próprio sistema alimenta as constantes contradições presentes no centro, sob a égide da perversidade estrutural que vigora até então.

\section{CONSIDERAÇÕES FINAIS}

Meu intento ao longo do artigo foi o de apontar o cinema como o resultado das várias invenções que compuseram o período tido como "Moderno", com base no aporte iconográfico. Além disso, tratei das possíveis leituras que a arte cinematográfica, mediante a observação de algumas cenas, assim como procurei relacioná-las às práticas sociais intrínsecas naquele momento. Ao longo do texto, é importante notar que não tive a pretensão de demonizar a tecnologia, mas fazer algumas observações de suas inconsistências sob a perspectiva do Cinema, que é parte constituinte dessa realidade.

O cinema surgiu no final do século XIX como consequência da Revolução Industrial na Inglaterra, entre os anos 1760 a 1780. Logo após tivemos a segunda Revolução, esta ocorrida por volta de 1850 a 1870 . Todavia, foi com base no aperfeiçoamento das técnicas utilizadas entre uma revolução e outra que alguns filmes foram projetados. É importante notar que tais acontecimentos foram o resultado do que se convencionou chamar de Modernidade. 
Fiz uma breve análise de Guernica, de Pablo Picasso, objetivando introduzir o conceito de Iconografia. Para tanto, busquei nos referencias teóricos de Carlos Ginzburg e Peter Burke a sustentação que necessitei para estruturar o artigo.

Em vista disso, o desafio de forjar as projeções cinematográficas, com base numa leitura iconográfica, passou pela ideia de trazer para o campo da história as várias possibilidades de compreensão da nossa realidade, como, também, procurei suscitar a multiplicidade e importância das imagens costuradas cotidianamente no imaginário das pessoas. Uma vez que o mundo esteve/está submerso nesse universo que não é novo, mas reinventado.

Esquadrinhei as imagens das obras selecionadas de forma a propor um exercício de reflexão para entendermos aquele período histórico. Foram feitas intervenções de caráter socioculturais dos impactos dos acontecimentos postos para nossos olhares de maneira mais clara, além de problematizar alguns detalhes correlacionados a uma sistemática leitura iconográfica da História, pensando no tempo inserido no recorte temporal como substância do capitalismo emergente.

Observar o tempo, no presente estudo, constitui aqui como fator que não surge com a modernidade, mas que encontra na sua organicidade, nas conexões dos seus inventos o alicerce para alterar, ou pelo menos transformar de maneira profunda as relações sociais do cotidiano daqueles sujeitos. Seu uso metafórico se deu com a representação dos distúrbios orgânicos de uma realidade difusa e carregada de uma disrupção do tecido social.

A sincronização das máquinas em funcionamento com os relógios mecânicos batendo os ponteiros estão postos de forma metafórica. Contudo, para trazer para a superfície dos acontecimentos esses pontos, me vali das imagens em movimento. Porém levei em consideração as práticas sociais daquele recorte histórico, ou seja, aquilo que estava ao redor, nas bordas.

Em síntese, finalizo afirmando que, na atual conjuntura, onde as imagens inundam avassaladoramente o cotidiano das pessoas, é imprescindível direcionar um olhar crítico e inquietante. Seja essa imagem um filme, um cartaz, uma fotografia, um desenho, ou outra qualquer que nos conduza para uma costura que transcenda o visível. Várias leituras são possíveis num documento escrito, numa oralidade, até mesmo nas projeções fílmicas, como procurei mostrar ao longo do artigo. Entretanto, para além do posto, do dito, e do visível, podem nos fazer enxergar uma série de possibilidades, circularidades e dinamismos que pulsam nas veias de um mundo ainda por ser estudado por meio de outros olhares. 


\section{REFERÊNCIAS}

BENJAMIN, Walter. Charles Baudelaire - Um lírico no auge do capitalismo. In: Obras escolhidas. Vol. III. São Paulo: Brasiliense, 1989.

BROUÉ, Pierre. A Revolução Espanhola: 1931-1939. São Paulo: Editora Perspectiva. 1992.

BURKE, Peter. Testemunha Ocular: o uso de imagens como evidência histórica. São Paulo: Unesp, 2017.

CAPELATO, Maria Helena; MORETTIN, Eduardo; NAPOLITANO, Marcos; SALIBA, Elias Thomé (Org.) História e Cinema. São Paulo: Alameda, 2011, p. 31.

CESARINO, Flávia. O Primeiro Cinema: espetáculo, narração, domesticação. Rio de Janeiro: Azougue, 2005.

CHARTIER, Roger. A história cultural: entre práticas e representações. Rio de Janeiro: Difel. 1988.

GINZBURG, Carlos. Medo, reverência, terror: quatro ensaios de iconografia política. São Paulo: Companhia das letras: 2014.

GIDDENS, Anthony. Modernidade e Identidade. Rio de Janeiro: Zahar, 2002, p.22.

HOBSBAWM, Eric J. A Era das Revoluções (1789-1848). São Paulo: Paz e Terra, 2011.

JOHNSON, Allan G. Dicionário de Sociologia - Guia prático da linguagem sociológica. Rio de Janeiro: Zahar, 1997. p. 188.

LEFEBVRE, Henri. O Direito à Cidade. Itapevi: Difel, 2016.

PINTO, Geraldo Augusto. A Organização do Trabalho no Século XX: taylorismo, fordismo e Toyotismo. São Paulo: Expressão Popular, 2007.

QUINTANEIRO, Tânia; BARBOSA, Maria Ligia de Oliveira; OLIVEIRA; Márcia Gardênia Monteiro. Um toque de Clássicos: Marx/ Durkheim/ Weber. Belo Horizonte: UFMG. $2^{\mathrm{a}}$ edição, 2009.

SCHMITT, Jean-Claude. A História dos Marginais. IN: LE GOFF, Jacques. A História Nova. São Paulo. Martins Fontes, 2011.

XAVIER, Ismail. A alegoria langeana e o monumental : a figura de babel em Metropolis. In:

História e Cinema. São Paulo. Alameda. 2011. p. 15-38. 